\title{
Effect of Improvised Instructional Materials on Students' Achievement in Geometry at the Upper Basic Education Level in Makurdi Metropolis, Benue State, Nigeria
}

\author{
Iji Clement $\mathrm{O}^{1, *}$, Ogbole Patience $\mathbf{O}^{1}$, Uka Nanna $\mathrm{K}^{2}$ \\ ${ }^{1}$ Department of Science Education College of Agricultural and Science Education, University of Agriculture, P. M. B. 2373, Makurdi \\ Benue State, Nigeria \\ ${ }^{2}$ Department of Mathematics Abia State Polytechnic Aba, Abia State, Nigeria \\ *Corresponding author: ijiclements07@yahoo.com
}

Received June 24, 2014; Revised July 03, 2014; Accepted July 10, 2014

\begin{abstract}
Among all approaches aimed at reducing poor mathematics achievement, adoption of appropriate methods of teaching appears to be more rewarding. In this study, improvised instructional materials were used to ascertain students' geometry achievement at the upper basic education one. Two research questions were asked while two hypotheses were formulated and tested at 0.05 level of significance. It adopted a quasi-experimental design of non-randomized pre-test post-test control group type. Carried out at Makurdi metropolis with a population of 1680 universal basic education (UBE) students. From this, 139 students were sampled from four schools out of the 22 UBE schools. Instrument of the study was Geometry Achievement Test (GAT). Research questions asked were answered using descriptive statistic of mean and standard deviation while the hypotheses formulated were tested using Analysis of covariance. The study found that students taught with improvised instructional materials improved on their geometry achievement. Also that both male and female student in the experimental group improved more on their geometry achievement than those of the control group. Recommendations such as encouraging mathematics teachers to use improvised instructional materials in their mathematics classroom were made among others. Relevant and adequate conclusions were also made.
\end{abstract}

Keywords: improvised instructional materials, students' achievement, Geometry, upper basic education, Makurdi metropolis

Cite This Article: Iji, Clement O, Ogbole Patience O, and Uka, Nanna K, "Effect of Improvised Instructional Materials on Students' Achievement in Geometry at the Upper Basic Education Level in Makurdi Metropolis, Benue State, Nigeria.” American Journal of Educational Research, vol. 2, no. 7 (2014): 538-542. doi: 10.12691/education-2-7-17.

\section{Introduction}

The study of mathematics generally is considered as basics for the preparation of every informed citizen and serves as a gateway into numerous career choices in life. D' Ambrosio (1997) stated that functional mathematics knowledge is the only true route to entering the modern world. This maybe why Soyemi (2005) opines that everybody uses mathematics in one way or the other in solving life problems. Nations that desire to forge ahead scientifically and technologically cannot afford to toy with the mathematical knowledge of her citizenry. This may be why more often than not, stakeholders in mathematics education always show concern about the mass failure of students in this subject at the public examinations.

Commenting on the achievement of candidates in mathematics, the West African Examination Council (WAEC) Chief Examiner (2007) reported that candidates were observed to be generally weak in geometry. Geometry is an aspect of school mathematics that has everyday application in the life of the child. It helps the child in the development of aesthetism around his/her environment as well as inductive reasoning skills. Ugwuanyi (2000) had earlier stated that geometry is one aspect of mathematics that is mostly dreaded by the students. Mathematics educators (Herbor-peters, 2001; Iji, 2002 and Obodo, 2007) have therefore been continuously exploring ways of ensuring that mathematics is properly taught and learned in schools. The implication here is that effective teaching of mathematics should emphasize active learning. The learners must personally be involved.

Agwagah (2000) had noted that mathematics teachers in most cases do not use instructional materials in their mathematics classroom, so most of the mathematics concepts are taught abstractly. This may be because some of the mathematics teachers believed that instructional materials to be used for teaching these mathematics concepts are not in existence. Even when they are 
available, there is this complain of lack of money by the mathematics teacher. This maybe one of the factors responsible for students' continuous failure in public mathematics examination in Nigeria.

Fanen (2005) stated that the availability and adequacy of instructional materials in schools for the teaching and learning of mathematics concepts was affect by several factors of which some are low level of educational funding in Nigeria, students' population explosion and even when provided, they are not related to the mathematical concepts being taught. It was observed that before now, governments (federal, states and local governments) have been taking the responsibility of providing some basic instructional materials, however, this is no longer so. The mathematics teachers must have to do something very urgent towards demystifying the learning of mathematics at the upper basic education level.

Piaget (1957) theory of concrete operational stage points that the mathematics teacher should be conscious of the developmental level of the learner. This becomes very important because majority of the upper basic education level students are still at the concrete operational level of intellectual development. This implies that mathematics teachers should adjust their teaching accordingly and ensure that mathematics is taught and learned by doing. The implication here is that where instructional materials are lacking, they should be improvised.

Odili (1990) asserts that improvised instructional materials may be used as practice devices with which the students build accuracy, understanding and efficiency. According to Dada (2006), improvised instructional materials involve the act of producing and using alternative resources aimed at facilitating instruction. Again, Ikwuas and Onwiodiket (2006) state that improvise materials involve selection and deployment of relevant instructional elements of the teaching and learning process in absence or shortage of standard teaching and learning materials for meaningful realization of specified educational goals and objectives. Abimbade (2004) had earlier noted that the approach of using improvised materials in mathematics classroom assist in proper introduction of new skills, develop understanding as well as show the appropriate way of doing things. It was on this ground that Kurumeh (2006) observed that the utilization of improvised instructional materials take adequate care of the three domains (Cognitive, affective and Psychomotor) thereby reducing the abstractness of the mathematics concepts.

The problem of students' poor achievement in mathematics has been a recurring decimal. This had necessitated consistent effort by stakeholders in mathematics education. Koran (2001) had considered the effect of motivation on students' achievement in mathematics. This was carried out in Kaduna state and adopted a pre-test post-test quasi-experimental design. The study found among other thing that students that were motivated achieved better in their mathematics achievement than those not motivated. Etukudo (2002) conducted a study on the effect of computer assisted instruction on gendre performance of junior secondary school students in mathematics. This study was carried out in Rivers state, Nigeria. It adopted a quasi-experiemental design with a population of 40 students (20 male and 20 female). It finally found that students' mathematics achievement is not dependent on gendre. To contribute further, Eze (2005) investigated the effect of improvised instructional materials on primary school pupils' achievement in mathematics. This was conducted in Kano municipal public schools - Kano State. It also adopted quasi-experimental design. The study revealed among others that pupils in the experimental group achieved better than those in the control group. Furthermore, Iyekekpolor and Tsue (2008) carried out a study that considered the effect of improvised instructional materials achievement in mathematics. The area of study was federal unity college in Taraba state. The result revealed a better mathematics on students' achievement in the experimental group. Equally Uloko and Usman (2008) used ethno-mathematics teaching approach and ascert students' achievement in locus. The population consist of 253 Senior Secondary two (SS2) students from zone B education zone of Benue state. The study revealed that students in the experimental group achieved better. From the fore going, it is obvious that efforts have been put in place to reduce poor achievement in mathematics by students at various levels of education. These were done in various areas of mathematics concepts ranging from algebra, trigonometry to loci. This has given room for this study to try the utilization of improvised instructional materials in the teaching of geometry at upper basic education level. It has also been observed that there exist inconsistency on gendre issue as it affects students achievement in mathematics generally. The issue then is, will the utilization of improvised instructional materials help to improve both male and female students' achievement in geometry?

\subsection{Purpose of the Study}

The main purpose of this study was to assert the efficacy of using improvised instructional materials on students' achievement in upper basic education level mathematics. Specially, the study was to determine

(i) whether the use of improvised instructional material could improve students achievement in geometry at the upper basic education level.

(ii) Find out if both gendre could improve on their achievement in geometry due to the use of improvised instructional materials.

\subsection{Research Question}

The following research questions were asked to provide guide for the study

(i) What are the mean achievement scores of students in the experimental and control groups as measured by the Geometry Achievement Test (GAT)?

(ii) What are the mean achievement scores of male and female students in the experimental and control group as measured by GAT?

\subsection{Research Hypotheses}

The following hypotheses were formulated and tested at 0.05 level of significance

(i) There is no significance difference between the mean achievement scores of students taught geometry using improvised instructional materials and those taught without improvised instructional materials in GAT 
(ii) There is no significance difference between the mean achievement scores of male and female students taught geometry using improvised instructional materials in GAT

\section{Methodology}

The research design adopted for this study was quasi experimental. It specifically used a non-randomized pretest post-test control design. The subjects of study were not randomized into experimental and control groups but were left as intact classes. This was to avoid the disruption of the school programmes. However, the classes were assigned into experimental and control groups. The study was conducted in Makurdi metropolis of Benue state, Nigeria. Makurdi serve as both the state capital and local government area headquarter. The study population was made up of 1680 upper basic education level one students from the 22 upper basic education schools in the study area. Simple random sampling of hat and draw method was used to select four schools from the 22 Universal basic education schools. The choice of basic education one was purposive. This was basically because this classes serve as transitional from concrete operational stage to formal stage. The sample size for the study was 139 from the population of 1680 students. This comprised of 61 students for control group and 78 students for the experimental group. The choice of which schools and classes to be used as experimental and control was done through simple random sampling with the use of a flip of a coin. The instrument of this study was the geometry achievement test (GAT). It consisted of 30 items made up of 18 lower order questions and 12 higher order questions. These items were developed in line with the instructional objectives as contained in the upper basic education one text book by the Mathematics Association of Nigeria (2004). GAT covered all the units taught during the period of this study. It was validated by two mathematics teachers, one mathematics educator and two measurement and evaluation experts. It has a reliability index of 0.86 , established using $\mathrm{KR}_{20}$. The study lasted for four weeks. Data collected and collated was analysed using analysis of covariance since it will statistically remove all initial differences across the non-randomized groups - by partitioning out the variation due to extraneous variables, thereby increasing the precision of the experiment.

\section{Result}

The results from analysis of data for this study is presented according to the research questions asked and hypotheses formulated.

\subsection{Research Question One}

What are the mean achievement scores of students in the experimental and control groups as measured by the Geometry Achievement Test (GAT)? The answer to this question is presented in Table 1.

From Table 1 the pre-GAT mean achievement scores show that the two groups were of the same cognitive level before the treatment. While the Post-GAT mean achievement scores indicate improvement of the experimental group over the control group.

Table 1. Mean achievement scores and standard deviation of students in the experimental and control groups

\begin{tabular}{|c|c|c|c|c|c|}
\hline & \multicolumn{3}{|c|}{ Pre-GAT } & \multicolumn{2}{c|}{ Post-GAT } \\
\hline Variables & $\mathrm{N}$ & $\mathrm{X}$ & $\mathrm{SD}$ & $\mathrm{X}$ & $\mathrm{SD}$ \\
\hline Experimental & 78 & 15.50 & 7.60 & 25.04 & 8.14 \\
\hline Group & & & & & \\
\hline Control group & 61 & 16.10 & 7.79 & 21.62 & 8.20 \\
\hline Total & 139 & & & & \\
\hline
\end{tabular}

The research hypothesis that further ascert this research question is in Table 2.

\subsection{Research Hypothesis One}

There is no significant difference between the mean achievement scores of students taught using improvised instructional materials and those taught without improvised instructional materials in GAT. The test of this hypothesis is presented in Table 2

Table 2. Two-way ANCOVA of the post-test achievement scores of students in geometry achievement test

\begin{tabular}{|c|c|c|c|c|c|c|}
\hline Sources & \multicolumn{2}{|c|}{$\begin{array}{c}\text { TypeIII sum of } \\
\text { square }\end{array}$} & Df & $\begin{array}{c}\text { Mean } \\
\text { square }\end{array}$ & $F_{\text {cal }}$ & $F_{\text {crit }}$ \\
\hline $\begin{array}{c}\text { Corrected } \\
\text { model }\end{array}$ & 5366.29 & & 2 & 2683.14 & 95.18 & 3.84 \\
\hline Intercept & 1805.39 & & 1 & 1805.39 & 64.05 & 3.84 \\
\hline $\begin{array}{c}\text { Pretest- } \\
\text { GAT }\end{array}$ & 5297.70 & & 1 & 5297.70 & 187.94 & 3.84 \\
\hline Group & 412.12 & & 1 & 412.12 & 14.62 & 3.84 \\
\hline Error & 3833.51 & 136 & 28.6 & & & \\
\hline Total & 79052.00 & 139 & & & & \\
\hline $\begin{array}{c}\text { Correct } \\
\text { Total }\end{array}$ & 9199.80 & 138 & & & & \\
\hline \multicolumn{7}{|c|}{$\mathrm{P} \leq 0.05$} \\
\hline
\end{tabular}

From Table 2, it could be seen that $\mathrm{F}_{\text {cal }}(1,138)=$ $14.62>\mathrm{F}_{\text {crit }}(3.84)$ at $\mathrm{P} \leq 0.05$ level of significance. Thus the hypothesis of no significant difference in mean achievement scores of students taught geometry using improvised instructional materials is rejected

\subsection{Research Question Two}

What are the mean achievement scores of male and female students in the experimental and control groups? The answer to this question is presented in Table 3.

Table 3. Mean achievement scores and standard deviation of male and female students in the experimental and control groups

\begin{tabular}{|c|c|c|c|c|c|c|}
\hline & \multicolumn{3}{|c|}{ Pre-GAT } & \multicolumn{3}{c|}{ Post-GAT } \\
\hline Variables & Sex & $\mathrm{N}$ & $\mathrm{X}$ & $\mathrm{SD}$ & $\mathrm{X}$ & SD \\
\hline Expmtal & Male & 42 & 15.71 & 7.55 & 24.07 & 8.84 \\
\hline Group & Female & 36 & 15.25 & 7.74 & 21.83 & 7.16 \\
\hline Control & male & 36 & 16.36 & 6.96 & 20.08 & 8.47 \\
\hline & Female & 25 & 20.60 & 8.37 & 23.84 & 7.40 \\
\hline Total & 139 & & & & & \\
\hline
\end{tabular}

Table 3 indicates that both the male and female students in the experimental group improved upon their mean achievement scores in the post-GAT more than the male and female students in the control group even though they had higher mean achievement scores in the pre-GAT.

The research hypotheses that further ascert this research question is in Table 4.

\subsection{Research Hypothesis Two}

There is no significant difference between the mean achievement scores of male and female students taught 
geometry using improvised instructional materials in GAT. The test result of this hypothesis is presented in Table 4.

Table 4. Summary of two-way ANOCA result of male and female students in experimental and control groups in geomentry achievement test

\begin{tabular}{|c|c|c|c|c|c|}
\hline Sources & $\begin{array}{c}\text { TypeIII } \\
\text { sum of } \\
\text { square }\end{array}$ & Df & $\begin{array}{c}\text { Mean } \\
\text { square }\end{array}$ & $\mathrm{F}_{\text {cal }}$ & $\mathrm{F}_{\text {crit }}$ \\
\hline Corrected model & 5435.24 & 4 & 1358.81 & 48.37 & 3.84 \\
\hline Intercept & 1741.46 & 1 & & & 3.84 \\
\hline Pretest-GAT & 5061.34 & 1 & 1741.46 & 61.99 & 3.84 \\
\hline Group & 19.05 & 1 & 5061.34 & 180.16 & 3.84 \\
\hline Sex & 373.87 & 1 & 19.05 & 0.68 & 3.84 \\
\hline Group*Sex & 39.95 & 1 & 373.87 & 13.31 & 3.84 \\
\hline Error & 3764.56 & 134 & 39.95 & 1.42 & \\
\hline Total & 79052.00 & 139 & 28.09 & & \\
\hline Correct Total & 9199.80 & 138 & & & \\
\hline \multicolumn{7}{|c|}{$\mathrm{P} \leq 0.05$} \\
\hline
\end{tabular}

The result from Table 4 indicates that $\mathrm{F}_{\text {cal }}$ of $13.31>$ $F_{\text {crit }}$ 3.84. Thus the hypothesis of no significant difference in the male and female mean achievement scores was rejected; hence, the use of improvised instructional materials improved male and female students' achievement in the geometry taught during this study more than those taught without improvised instructional materials.

\subsection{Summary of Findings}

The following major findings were based on the data presented for this study.

1. Students taught geometry during this study improved upon their mean achievement scores due to the utilization of improvised instructional materials.

2. Both male and female students in the experimental group improved upon their geometry taught during the period of the study.

\subsection{Discussion of Findings}

The indication of the result that students taught geometry with improvised instructional materials improved upon their mean achievement scores in postGAT was a welcome development. The reason for this, may have been that students were stimulated to learn by the use of improvised instructional materials that may have equally brought about competitiveness and enlivened the students to learn. These materials may have provided enthusiasm, excitement, as well as total involvement and enjoyment of the lesson. Again, the contents learnt were arranged according to the students' cognitive level. This may properly be in tune with the Piagetian theory of concrete operational stage that pointed out the need for mathematics teachers to be conscious of the developmental level of their students. Thus the results of this study has revealed that the adoption of appropriate classroom instructional strategy would enhance a meaningful learning of any mathematics concept. This finding tend to be in line with Abimbade (2004), Eze (2005) who had earlier shown that students demonstrated greater understanding of mathematics concepts as well as improved upon their mathematics achievement due to the utilization of appropriate instructional strategy in the mathematics classroom. This result is also in line with the outcome of Kurume (2006) who found that the utilization of improvised instructional materials in mathematics classroom enhance the development of learners' cognitive, affective and psychomotor domains.

Again, it is interesting to note that both male and female students improved upon their geometry achievement test during the period of this study. The implication here is that utilizing improvised instructional materials in the mathematics classroom is gendre friendly. With more female embracing mathematics mean more female scientists, engineers and more female participation in the technological development of the nation. This finding tends to be in line with Etukudo (2002) who found that there was no significant difference among the male and female students in mathematics achievement test. It is equally in agreement with Iyekekpolor and Tsue (2008) and Usman (2008) who all found that there is no gendre discrimination in mathematics achievement any time an appropriate and adequate method is adopted in the teaching of any mathematics concept.

\section{Recommendations}

Based on the findings of this study the following recommendations are made

1. Mathematics teachers should make deliberate effort to embrace the attitude of improvising instructional materials in their mathematics classroom.

2. Workshop and seminars should be organized by stakeholders in mathematics education for in-service mathematics teachers on the need for improvisation

3. Mathematics teachers should be made to ensure that the improvised materials are relevant to the mathematics concepts that they will be used.

\section{Conclusion}

The adoption of appropriate method(s) of teaching generally and in particular, at the mathematics classroom has shown that subjects exposed to such method(s) improved upon their mathematics achievement. This was clearly shown since the utilization of improvised instructional materials in this study enhance students' achievement in geometry. Not only that, male \& female students' in this study, equally improved upon their achievement in the geometry taught during the period of this study

\section{References}

[1] Abimbade CT (2004). Effective primary school science teaching: Meaning, scope and strategies in T. O. Oyetunde, Y.A. Mallam and G. A. Andzagi (ed). The practice of teaching perspective and strategies pp 179-186. Jos: LECAPE Publishers.

[2] Agwagah UNV (2001).Teaching number bases. In V.F.HarborPeters (ed). Mathematics language for the new millennium: implication for the society. Proceeding of Science Teachers' Association of Nigeria 125-127.

[3] Dada R (2006). Dynamics of teaching Secondary School mathematics. Lodon: Rutledge

[4] D' Ambrosio U (1997). Ethnomathematics and lits place in the History and pedagogy of mathematics-New York: State University of New York press.

[5] Etukudo UE (2002). The effect of computer assisted instrumentation in gendre and performance of junior secondary 
school students in mathematics. J.Mathematical Association of Nigeria. 27 (1), 1-8.

[6] EzeAF (2005). Promoting self control of mathematics learning for preservice primary teachers. Australia: University of Melbourne.

[7] Fanen SU (2005).Improvising in science teaching philosophy and practice. Abakiliki: Belpot (Nig) limited.

[8] Harbor-Peters VF (2001).Unmasking some aversive aspect of school mathematics and strategies for averting them. Inaugural lecture.

[9] Iji CO (2002).Effect of Logo and Basic programme on the achievement and retention in geometry of junior secondary school students. Unpublished Ph.D thesis, university of Nigeria, Nsukka.

[10] Ikwuas OA, Onwiodiket Y (2006). Mathematics Phobia: Diagnsis and prescription. First annual lecture: National mathematics centre, Abuja.

[11] Iyekekpolor,S A, Tsue AE (2008).Effect of computer assisted instruction on students' achievement in mathematics. J.Research in curriculum and teaching. 3 (1), 211-216.

[12] Kurumeh MS (2006). Effect of ethnomathematics approach on students' achievement in geometry and menstruation. J.mathematical Association of Nigeria. 31 (1), 35-44.
[13] Koran I (2001).Teachers and students motivation effects on students' achievement at junior secondary school level. J. Mathematical Association of Nigeria. 26 (1), 35-41.

[14] Mathematics Association of Nigeria (2004). MAN Mathematics for Junior Secondary schools book one $3^{\text {rd }}$ edition. Ibadan: university press Plc.

[15] Obodo JC (2007).Evaluation of available resources materials in secondary school. Int J. of Education Research. 4 (1); 62-69.

[16] Odili GA (2006).Mathematics in Nigerian secondary schools. A teaching perspective Port Harcourt: Anachuna Educational books.

[17] Piaget J (1957). The construction of reality in the child. New York: Basic Books.

[18] Soyemi T (2005). Into the classroom with behavior modification. The school councilor. Pp 110-113.

[19] Ugwuanyi C (2000). Generating interest in the teaching and learning of sequence andseries through the use of games and simulation. Journal of Issues on mathematics. 5 (1), 40-48.

[20] Uloko ES, Usman KO (2008).Effect of ethno-mathematics teaching approach on students' interest and achievement in Locus. Benue Journal of Research in science education. 1 (1), 81-91.

[21] West African Examination Council (WAEC) (2007) chief Examiner's Report. Laogos. 